\title{
Оцінювання персоналу військової організаційної структури під час виконання ним завдань за призначенням
}

\author{
В'ячеслав Косевцов ${ }^{1}$ А; Вадим Машталір ${ }^{2}$ в; Григорій Тіхонов ${ }^{3}$ А; \\ Олександр Білик ${ }^{4}$ A \\ А Національний університет оборони України імені Івана Черняховського, пр-кт Повітрофлотський 28, м. Київ, 03049, Україна \\ в Генеральний штаб Збройних Сил України, пр-кт Повітрофлотський 6, м. Київ, 03168, Україна
}

Received: August 1, 2021 | Revised: August 23, 2021 | Accepted: August 31, 2021

DOI: $10.33445 /$ sds.2021.11.4.3

\begin{abstract}
Анотація
Стаття присвячена дослідженню процесу оцінки персоналу військової організаційної структури з метою підвищення спроможностей їі персоналу у виконанні завдань, що стоять перед нею. У статті розглянуті сучасні наукові тенденції щодо визначення системи оцінки персоналу та питання з підвищення його ефективності, сформовано основні проблемні аспекти питань оцінки персоналу. Визначено напрямки удосконалення оцінки персоналу, здійснено їх загальну характеристику та шляхи подальшого ї̈ розвитку.
\end{abstract}

Ключові слова: персонал, управління персоналом, оцінка персоналу, атестування, військова організаційна структура.

\section{Постановка проблеми}

Недоліки 3 призначення окремих військовослужбовців викликали незадоволення у засобах масової інформації 3 питань як висновків атестації та особистостей окремих військовослужбовців. Особового розмаху це явище набуло у соціальних мережах. Треба підкреслити, що з часом ці явище будуть лише наростати, як свідчить досвід західних країн. Внаслідок цього система оцінки персоналу, ії дослідження 3 метою підвищення ефективності мають високу актуальність та вимагають свого подальшого теоретичного обґрунтування.

\section{Аналіз останніх досліджень та публікацій}

Проведення антитерористичної операції та операції Об'єднаних сил гостро поставило проблему підвищення якості та ефективності управління персоналом Збройних Сил України, насамперед, кваліфікованими військовими кадрами [1], які можуть бути визначені лише шляхом об'єктивної оцінки та атестації. Разом з тим в начальний період проведення бойових дій, внаслідок попередніх помилок в плануванні розвитку Збройних Сил України, комплектування персоналом відбувалося не в повній мірі ефективно, що не дозволяло своєчасно та якісно виконувати завдання та призначати на відповідні посади найбільш достойних представників.

\section{Постановка завдання}

Метою статі $\epsilon$ розгляд теоретичних положень та практичних рекомендацій щодо подальшого дослідження ефективності оцінки персоналу 3 метою підвищення бойових спроможностей військових організаційних структур у Збройних Силах України.

\footnotetext{
${ }^{1}$ Corresponding author: д. військ. н., професор, професор кафедри, e-mail: kosevtsov@ukr.net

2 к. істор. н., доцент, e-mail: vadim_mashtalir@ukr.net

${ }^{3}$ канд. війс. наук, старший науковий співробітник, начальник кафедри, e-mail: tikhonov2404@ukr.net

${ }^{4}$ здобувач наукового ступеня, e-mail: alexanderbilyk@ukr.net
} 


\section{Виклад основного матеріалу}

Використання персоналу ВОС передбачає реалізацію таких базових функцій управління персоналом як його оцінка (включаючи оцінку потенціалу, службових зусиль і результатів виконання службових обов'язків) та мотивація персоналу.

Оцінка - одна з найскладніших категорій повсякденного життя, філософії, педагогіки, психології, менеджменту. Вона має місце у всіх формах життєдіяльності людини, в ході здійснення яких він пізнає навколишній світ і самого себе. Під оцінкою персоналу звичайно розуміють цілеспрямоване порівняння певних характеристик (професійнокваліфікаційного рівня, ділових якостей, результатів праці) працівників з відповідними параметрами, вимогами, еталонами. Оцінка $\epsilon$ універсальною властивістю суб'єкта (керівника, начальника), завдяки якому він з усього різноманіття навколишнього персоналу вибирає ті об'єкти (підлеглих), які представляються для нього цінніснозначущими, необхідними для існування та якісного виконання завдань, що стоять перед ВOC (рис. 1).

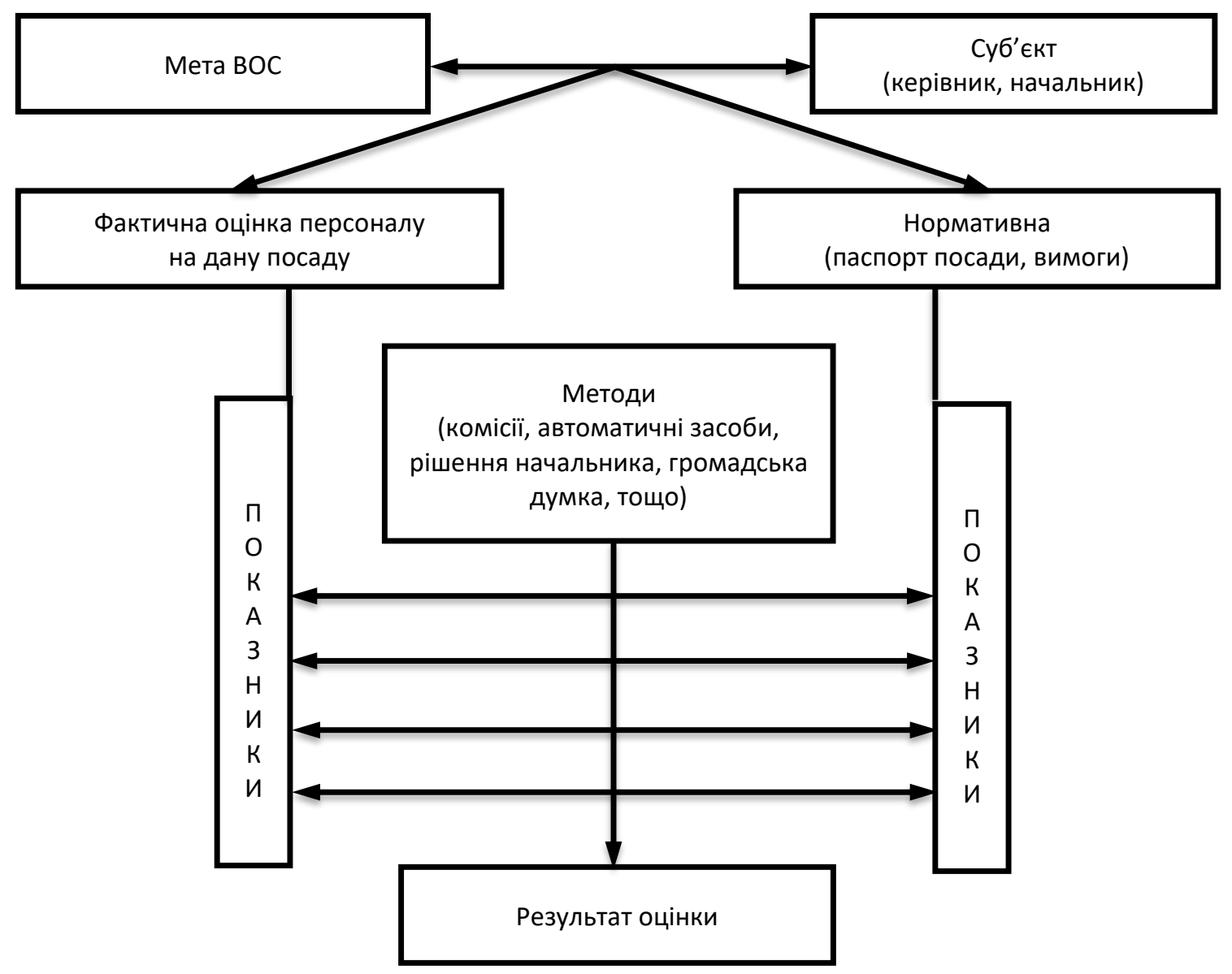

Рис. 1 - Структура процесу оцінки персоналу

Оцінка персоналу має базуватися на загальновизнаних принципах, а саме: об'єктивності, усебічності; обов'язковості; систематичності (постійності). Дотримання цих принципів дає змогу використати оцінку персоналу для: а) підбору й розстановки нових військовослужбовців;

б) прогнозування просування військовослужбовців по службі;

в) раціоналізації стандартів і методів робіт з управління персоналом; 
г) побудови ефективної системи мотивації службової діяльності;

д) оцінки ефективності діяльності окремих військовослужбовців і підрозділів.

Оцінка взагалі, безвідносно до певної галузі, допускає наявність якоїсь нормативної моделі (паспорт посади, нормативні вимоги) і фоктичної, реальної ситуації (реального представника персоналу з його показниками).

Перша служить еталоном (з чим порівнюємо), а друга - об'єктом (що порівнюємо). Порівняння відбувається за допомогою спеціальних методів, прийомів і процедур. Однак порівнювати еталон та об'єкт загалом часто не представляється можливим, тому в них виділяються деякі параметри, характеристики, показники, що відображають сутність об'єкта. Надалі саме вони порівнюються один з одним. Остаточна оцінка може бути отримана наступними шляхами:

включенням результатів вимірювань об'єкта в ті чи інші еталонні групи, наприклад, відповідних і невідповідних якимсь встановленим вимогам (спосіб заданого групування);

поданням в певній послідовності (ранжируванням у відповідності зі ступенем прояви необхідних якостей, рейтенгуванням).

“Оцінювання - це процес отримання оцінки, що включає підготовку, вибір предмета i суб'єкта оцінки, ії інтерпретація і використання отриманих результатів" [1]. Таким чином, в широкому сенсі оцінка як процес являє собою комплекс заходів підготовчого характеру: обгрунтування вибору об'єкта, предмета (які факти, характеристики, показники або значення підлягають оцінці), суб'єкта оцінки (хто оцінює), вибір методів та інструментів оцінки (за допомогою чого відбувається вимір стану предмета оцінки), формування технології та процедур оцінки (яким чином, в якій послідовності суб'єкт використовує методи, інструменти), змістовного (безпосередньо процес) i заключного (інтерпретація та використання результатів оцінки) етапів (рис. 2).

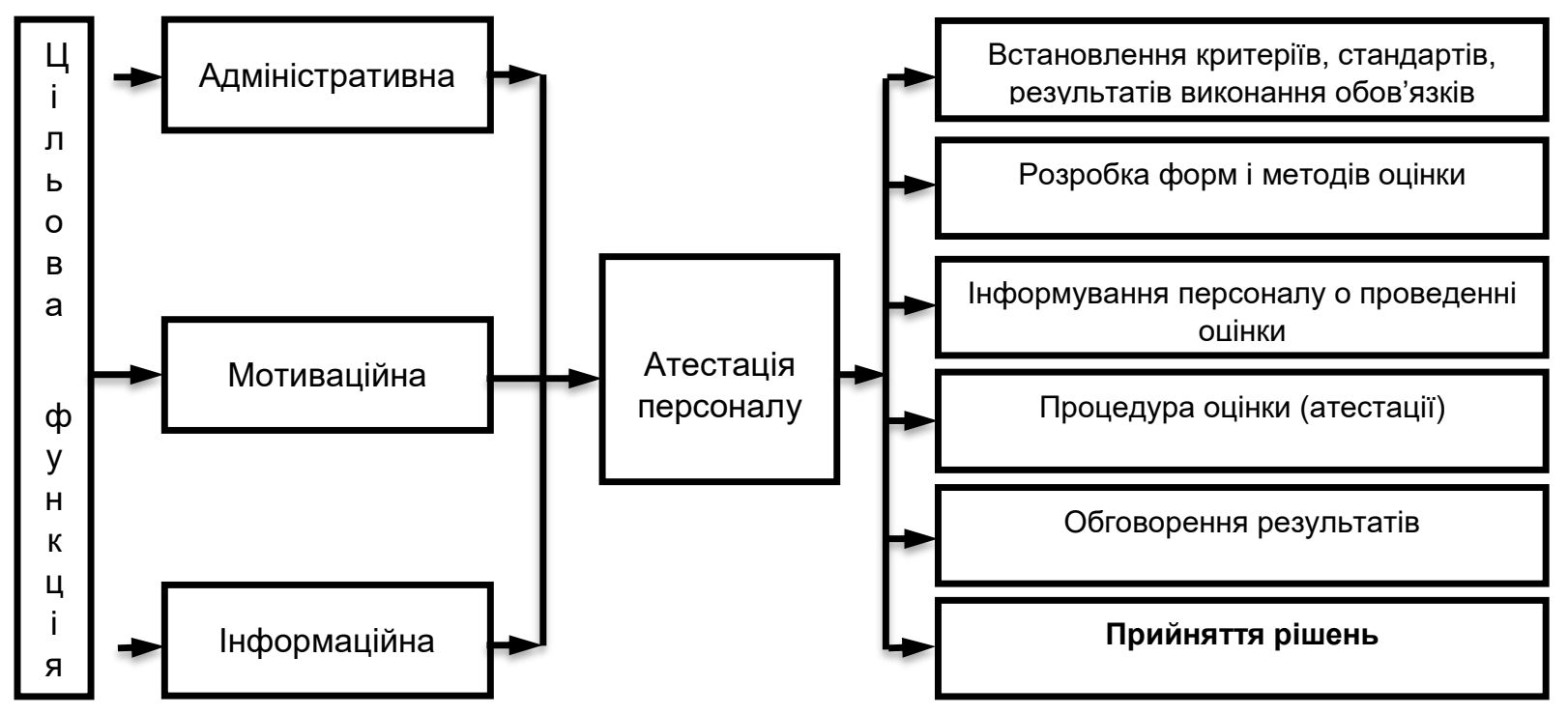

Рис. 2 - Алгоритм роботи з оцінки персоналу

Оцінка являє собою вироблення думки (судження) про якісний стан якого-небудь об'єкта на основі порівняльного аналізу (з використанням якісних та (або) кількісних методів) з аналогічним об'єктом (групою об'єктів) або ідеальною моделлю, що володіють характеристиками, подібними характеристиками оцінюваного об'єкта.
Отже, для того щоб оцінка була коректною, порівнювані об'єкти повинні бути порівнянні.

Оцінка - процес діяльності людей. Як будь-який інший процес вона має послідовність свого здійснення. Особливості процесу оцінки визначаються об'єктом оцінки, тобто тим, що піддається оцінці. Характерна особливість оцінки персоналу 
полягає в тому, що у всіх можливих випадках безпосередня участь людини в процесі оцінки не завжди $\epsilon$ обов'язково і може виражатися тільки в остаточному ухваленні рішення за результатами оцінки, то оцінюючи людину (їх групу), не можна покладатися тільки на технічні пристрої, тобто діяльну присутність людини (комісії), яка провадить оцінку, необхідно на всіх стадіях процесу оцінки персоналу контролювати, починаючи від визначення мети, процедури оцінки і закінчуючи прийняттям рішення.

Таким чином, суб'єкт оцінки - це людина (група людей, комісія), які виробляють оцінку об'єкта та вимагають постійного контролю [4]. Головою комісії, як правило, призначається заступник командира ВОС i внаслідок цього він мати упереджене ставлення до кандидата. При цьому в організації існує кілька груп суб'єктів оцінки, підключення кожної з яких до процесу оцінки залежить від поставленої мети здійснення оцінки персоналу.

У процесі оцінки персоналу суб'єкти оцінки за допомогою певних методів виробляють власну думку про якісний стан предмета оцінки, в результаті чого, У відповідності 3 поставленими цілями, приймається кадрове рішення про подальшу долю об'єкта оцінки. Можливо виділити наступні групи суб'єктів по відношенню до об'єкта оцінки персоналу, а саме:

вище керівництво:

безпосереднього начальника;

колег (військовослужбовців, що займають одну посадову щабель з об'єктом оцінки);

самого військовослужбовця (самооцінка); експертів.

Mета здійснення оцінки - прийняття кадрового рішення, як правило, заснованого на виборі. Таким чином, залежно від отриманої оцінки військовослужбовець або комісія, які виробляють оцінку, буде діяти надалі тим чи іншим чином. Феномен системи оцінки персоналу полягає в тому, що вона інтегрує в собі різні підходи.

Оцінка, що проводиться в інформаційних цілях, служить для того, щоб військовослужбовці знали про рівень власної роботи $\mathrm{i}$ могли поглянути на себе 3 боку. Співробітникам всіх рівнів важливо бачити i розуміти, що робить кожен з них, яким чином результат його роботи вписується в загальний результат підрозділу. Необхідність такої інформаційної складової підсумків оцінки персоналу безпосередньо пов'язана 3 мотивацією персоналу.

Мотиваційна мета оцінки персоналу полягає у тому, щоб правильно визначити можливі методи мотивації (наприклад, матеріальної, моральної) поведінки персоналу. Також мотиваційна складова оцінки персоналу дозволяє виявити своєчасність зворотного зв'язку між керівниками та підлеглими за підсумками своєї роботи.

Оцінка персоналу (рис. 2) є процес оцінки ефективності виконання військовослужбовцем своїх посадових обов'язків, результативності його діяльності, розвитку компетентності і повинен носити комплексний характер (рис. 3).

Результати оцінки персоналу повинні бути взаємопов'язані з основними цілями оцінки щодо підвищення стандартів військової організаційної структури. На практиці за результатами оцінки частіше приймаються адміністративні рішення, наприклад, призначення на посади, зміна планування розвитку та навчання персоналу.

Аналіз інформаційних та мотиваційних аспектів діяльності персоналу за допомогою оцінки дає можливість подивитися на цю процедуру очима співробітниківвійськовослужбовців, оцінити, наскільки правильно вони її розуміють, виявити ставлення до неї. За допомогою цих результатів можливо коректувати систему професійної підготовки, виявити особливості відносин між керівником і підлеглим, а також формувати службову культуру ВОС. Тому результати оцінки персоналу - це інформація не тільки для безпосереднього та старшого керівника і менеджера з персоналу, а й для самого військовослужбовця, що оцінювався. 


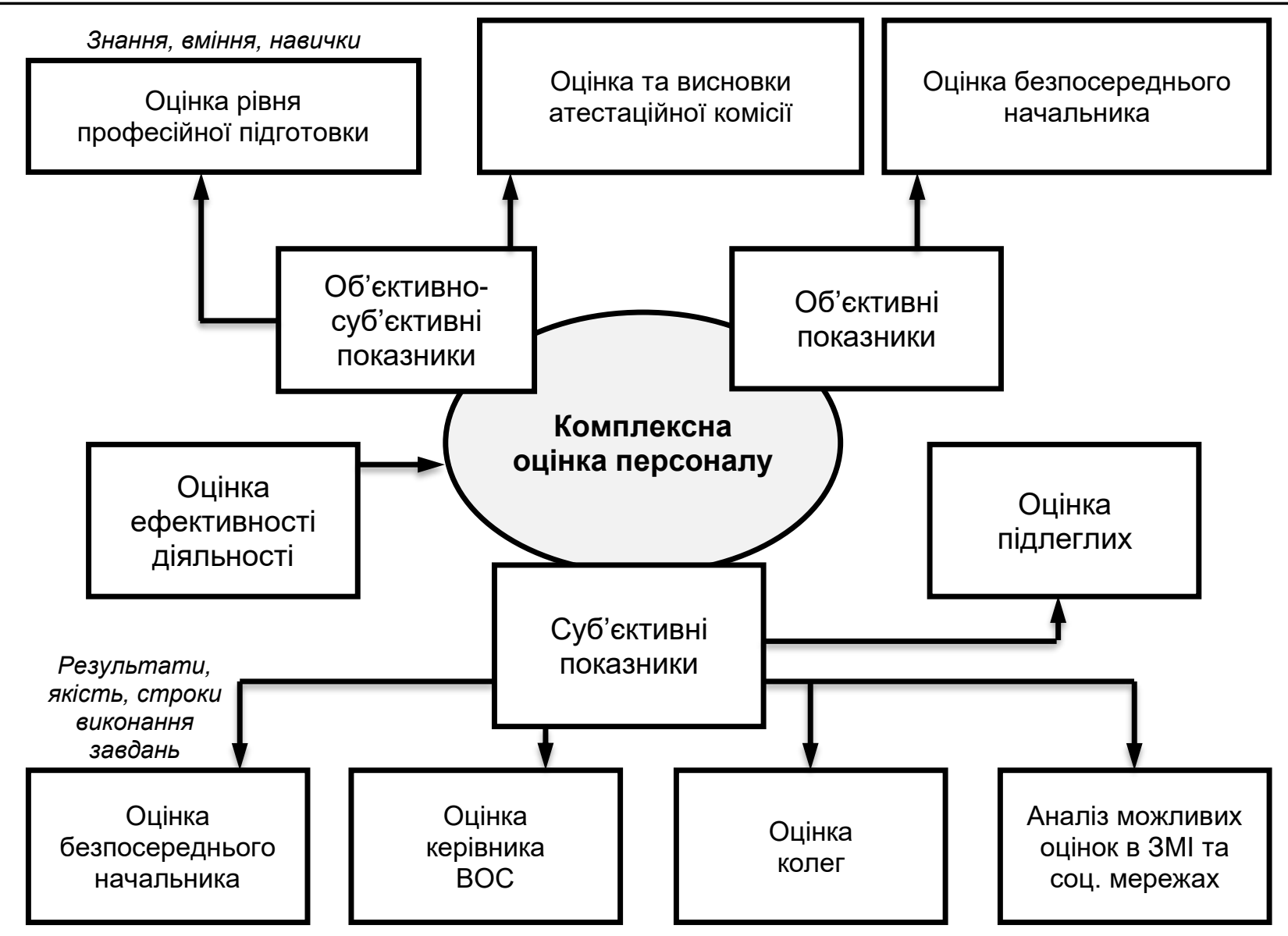

Рис. 3 - Структура комплексної оцінки персоналу, що пропонується

Оцінка персоналу залишається однією 3 найважливіших функцій управління персоналом, невід'ємним і найважливішим елементом в структурі персонального менеджменту сучасної військової організаційної структури. Її роль у системі менеджменту полягає в тому, що саме на основі отриманої інформації управлінський суб'єкт (керівник ВОС, начальник служби персоналу та ін.) приймають найбільш раціональне рішення. Від того, наскільки ця інформація буде якісною і надійною, в кінцевому рахунку, залежить ефективність подальшого підвищення навчально-бойових стандартів ВОС.

Значення оцінки високо ще й тому, що вона пов'язує, об'єднує всі елементи системи управління персоналом в єдине ціле. Без оцінки відповідних службових, особистісних чи професійних якостей військовослужбовців неможливо здійснити управління персоналом ні по одному 3 напрямків: планування персоналу, відбір, адаптація, стимулювання служби, розвиток здібностей, службові переміщення і планування кар'єри, згуртування колективу, вивільнення персоналу і ін.

Разом з тим в управлінні персоналом проблеми оцінки залишаються найменш розробленими в теоретичному і практичному плані. У сучасній теорії робиться акцент, насамперед на методи оцінки в деяких 3 елементів системи управління персоналом (найчастіше при відборі, кар'єрних переміщеннях). При цьому характеризуються окремо питання оцінки особистісних якостей військовослужбовців. Людина розглядається в одному випадку як особистість, в іншому як носій певних службових результатів. Тим часом вже доведено, що результативність службової діяльності військовослужбовця істотно залежить і від ділових, і від особистісних якостей людини. Отже, оцінка персоналу повинна носити комплексний 
характер.

Оцінка персоналу повинна бути визначена як планова, формалізована і стандартизована оцінка персоналу ВОС на основі заданих критеріїв протягом усього періоду службової діяльності військово-службовця. Основне завдання оцінки персоналу - допомога командиру в управлінні персоналом: розвитку військовослужбовців на основі їхніх особистих здібностей і цілей ВОС, формування кадрового резерву, ротації і т.д.
Процедура оцінки повинна строго відповідати нормам встановленим у законах України та нормативних документах Міністерства оборони України. Оціночні заходи повинні проводитися на такому якісному рівні, щоб органічно включитися в загальну систему кадрової роботи в організації, сприяти їі розвитку i вдосконалення. Вони не повинні вести до виникнення конфліктних ситуацій в колективі і т.д.

\section{Висновки}

Подальше висвітлення даної проблеми полягає в широкому застосуванні оцінки персоналу у ВОС з метою підвищення якості у прийнятті кадрових рішень та автоматизації процесу кадрового планування спрямованого на створення якісного резерву персоналу для підвищення ефективності впровадження військової кадрової політики в Збройних Силах України.

\section{Список використаних джерел}

1. Про Збройні Сили України: Закон України від 06.12.1991 № 1934-XII. URL: https://zakon.rada.gov.ua/laws/show/193412\#Text [дата зверн.: 27.07.2021].

2. Балабанова Л. В., Сардак О. В. (2011). Управління персоналом. Київ: Центр учбової літератури, 468 с.

3. Данюк В. М., Петюх В. М., Цимбалюк С. О. (2004) Менеджент персоналу. Київ: KHEY, $398 \mathrm{c}$.

4. Дмитренко, Г. А., Шарапатова, Е. А., Максименко, Т. М. (2002) Мотивація и очінка персонала. Київ: МАУП, 248 с.

5. Іванісов, О. В., Доровський, О. Ф. (2012) Удосконалення системи оцінки персоналу за рахунок використання формалізованорейтингової системи атестації працівників на підприємстві. Комунальне господарство міст: Науково-технічний збірник. № 106, С. 372-378.

6. Крушельницька, О. В., Мельничук, Д. П. (2003) Управління персоналом. Київ: Кондор, 296 с.

7. Савченко В. А. (2002) Управління розвитком персоналу. Київ: КНЕУ, 351 с.
8. Сиротенко А. М., Думенко М. П., Тіхонов Г. М., Кірілкін Є. І. (2017) Управління персоналом у збройних Силах України. Київ; НУОУ, 407с.

9. Федулова Л.І., Сокирник І. В., Стадник В. В., Йохна М. А., Новикова О. С., Рясних Є.Г. (2004) Менеджмент організацій. Київ: Либідь, 448 с.

10. Методичні рекомендації з порядку формування і використання Резерву кандидатів для просування по службі у збройних Силах України, затверджені директором Департаменту кадрової політики Міністерства оборони України від 19.03.2018 № 350 (2019). URL: https://www.mil.gov.ua/content/other/mrk _rezerv_2019.pdf [дата зверн.: 27.07.2021]

11. Про затвердження Інструкції про організацію виконання Положення про проходження громадянами України військової служби у Збройних Силах України: наказ Міністра оборони України від 10.04.2009 № 170. URL: https://zakon.rada.gov.ua/laws/show/z043 8-09\#Text [дата зверн.: 27.07.2021].

\section{Оценка персонала военной организационной структуры при}

\section{выполнении им задач по назначению}




\title{
Вячеслав Косевцов * 1 А; Вадим Машталир 2 в; Григорий Тихонов ${ }^{3 \text { A; }}$ Александр Билык ${ }^{4}$ А
}

Corresponding author: ${ }^{1}$ д.в.н., професор, профессор кафедры, e-mail: kosevtsov@ukr.net 2 доктор ист. наук, доцент, начальник управления ГШ ВС Украины, e-mail: vadim_mashtalir@ukr.net ${ }^{3}$ канд. воен. наук, старший научный сотрудник, начальник кафедры, e-mail: tikhonov2404@ukr.net ${ }^{4}$ Соискатель ученой степени, e-mail: alexanderbilyk@ukr.net

А Национальный университет обороны Украины имени Ивана Черняховского, пр-кт Воздухофлотский, 28 г. Киев, 03049, Украина в Генеральный штаб Вооруженных Сил Украины, пр-кт Воздухофлотский, 6, г. Киев, 03168, Украина

\section{Аннотация}

Статья посвящена исследованию процесса оценки персонала военной организационной структуры с целью повышения возможностей ее персонала в выполнении задач, стоящих перед ней. В статье рассмотрены современные научные тенденции определения системы оценки персонала и вопросы по повышению его эффективности, сформированы основные проблемные аспекты вопросов оценки персонала. Определены направления совершенствования оценки персонала, осуществлена их общая характеристика и пути дальнейшего ее развития.

Ключевые слова: персонал, управление персоналом, оценка персонала, аттестация, военная организационная структура.

\section{Evaluation of the personnel of the military organizational structure in the performance of their assigned tasks}

\author{
Vyacheslav Kosevtsov * 1 A; Vadim Mashtalir 2 B; Grigory Tikhonov 3 A; \\ Aleksandr Bilyk 4 A \\ Corresponding author: ${ }^{1} \mathrm{Dr}$ of military sciences, professor, professor department, e-mail: kosevtsov@ukr.net \\ ${ }^{2}$ Dr of Historical Sciences, Associate Professor, Head of the Personnel Management Department, e-mail: vadim_mashtalir@ukr.net \\ ${ }^{3}$ Candidate of Military Sciences, Senior Researcher, Chief of Department, e-mail: tikhonov2404@ukr.net \\ ${ }^{4}$ Applicant for a scientific degree, e-mail: alexanderbilyk@ukr.net

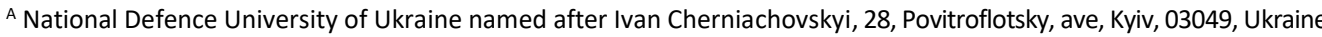 \\ ${ }^{B}$ General Staff of the Armed Forces of Ukraine, 6, Povitroflotskyi Ave., Kyiv, 03168, Ukraine
}

\begin{abstract}
The article is devoted to the study of the process of assessing the personnel of a military organizational structure in order to increase the capabilities of its personnel in performing the tasks facing it. The article discusses modern scientific trends in determining the personnel assessment system and issues of increasing its efficiency, the main problematic aspects of personnel assessment are formed. The directions for improving the assessment of personnel have been determined, their general characteristics and the ways of its further development have been carried out.
\end{abstract}

Keywords: personnel, personnel management, personnel assessment, appraisal, military organizational structure.

\section{References}

1. Pro Zbroini Syly Ukrainy [About Zbroyny Strength of Ukraine]: Zakon Ukrainy vid 06.12.1991 № 1934-XII (1991). Available from: https://zakon.rada.gov.ua/laws/ show/1934-12\#Text [Accessed: 27.07.2021].

2. Balabanova, L. V. \& Sardak, O. V. (2011). Upravlinnia personalom ["Personnel management"]. Kyiv: Tsentr uchbovoi literatury, $468 \mathrm{~s}$.

3. Daniuk V. M., Petiukh V.M. \& Tsymbaliuk S. O. (2004) Menedzhment personalu [Personnel management]. Kyiv: KNEU, $398 \mathrm{~s}$. 4. Dmytrenko, H. A., Sharapatova, E. A. \& Maksymenko, T. M. (2002) Motyvatsiia y 
otsinka personala [Motivation and evaluation of staff]. Kyiv: MAUP, $248 \mathrm{~s}$.

5. Ivanisov, O. V. \& Dorovskyi, O. F. (2012) Udoskonalennia systemy otsinky personalu za rakhunok vykorystannia formalizovanoreitynhovoi systemy atestatsii pratsivnykiv na pidpryiemstvi [Improving the system of personnel evaluation through the use of formalized-rating system of certification of employees at the enterprise]. Komunalne hospodarstvo mist: Naukovo-tekhnichnyi zbirnyk. № 106, s. 372-378.

6. Krushelnytska, O. V. \& Melnychuk, D. P. (2003) Upravlinnia personalom [Personnel management]. Kyiv: Kondor, $296 \mathrm{~s}$.

7. Savchenko V. A. (2002) Upravlinnia rozvytkom personalu [Personnel development management]. Kyiv: KNEU $351 \mathrm{~s}$.

8. Syrotenko A. M., Dumenko M.P., Tikhonov H. M. \& Kirilkin Ye.I. (2017) Upravlinnia personalom u Zbroinykh Sylakh Ukrainy [Personnel management at the Zbroynykh Forces of Ukraine]. Kyiv; NUOU, $407 \mathrm{~s}$.

9. Fedulova L. I., Sokyrnyk I. V., Stadnyk V. V., Yokhna M. A., Novykova O. S., Riasnykh Ye. H.
(2004)
Menedzhment
orhanizatsii
[Organizational management]. Kyiv; Lybid, $448 \mathrm{~s}$.

10. Metodychni rekomendatsii z poriadku formuvannia i vykorystannia Rezervu kandydativ dlia prosuvannia po sluzhbi u Zbroinykh Sylakh Ukrainy, zatverdzheni dyrektorom Departamentu kadrovoi polityky Ministerstva oborony Ukrainy vid 19.03.2018 № 350 (2019). Available from: https://www.mil.gov.ua/content/other/mrk _rezerv_2019.pdf [Accessed: 02.07.2021].

11. Pro zatverdzhennia Instruktsii pro orhanizatsiiu vykonannia Polozhennia pro prokhodzhennia hromadianamy Ukrainy viiskovoi sluzhby u Zbroinykh Sylakh Ukrainy [About the statement of the Instruction on the organization of execution of the Situation on passing by citizens of Ukraine of military service in the Armed Forces of Ukraine]: nakaz Ministra oborony Ukrainy vid 10.04.2009 № 170 (2009). Available from: https://zakon.rada.gov.ua/laws/show/z043 8-09\#Text [Accessed: 27.07.2021]. 